ZOOLOGIA 30 (4): 451-457, August, 2013

http://dx.doi.org/10.1590/S1984-46702013000400013

\title{
A new species of Bogidiella (Crustacea: Amphipoda: Bogidiellidae) from bore wells in Andhra Pradesh, Southern India
}

\author{
André R. Senna ${ }^{1}$, Riccardo Mugnai ${ }^{2}$ \& Yenumula Ranga Reddy ${ }^{3}$
}

\author{
${ }^{1}$ Curso de Ciências Biológicas, Centro Universitário de Volta Redonda. Avenida Paulo Erlei Alves Abrantes 1325, Prédio 1, \\ Três Poços, 27240-560 Volta Redonda, RJ, Brazil. E-mail: senna.crustacea@gmail.com \\ ${ }^{2}$ Departamento de Invertebrados, Museu Nacional, Universidade Federal do Rio de Janeiro. Quinta da Boa Vista, São \\ Cristóvão, 20940-040 Rio de Janeiro, RJ, Brazil. \\ ${ }^{3}$ Department of Zoology, Acharya Nagarjuna University. Nagarjunanagar 522 510, India.
}

\begin{abstract}
A new amphipod species of Bogidiellidae Hertzog, 1936 is described and illustrated based on specimens collected from bore wells in the state of Andhra Pradesh, Southern India. The new species is closely related to those belonging to a group of Bogidiella species with inner rami of pleopods reduced or absent. Bogidiella totakura sp. nov. differs from all the other species in the group mainly by the shape, size and ornamentation on gnathopods and telson. This is the second Indian species of Bogidiella.
\end{abstract}

KEY WORDS. Amphipod; biodiversity; Bogidiella totakura sp. nov.; stygobiotic; taxonomy.

Ongoing faunistic investigations of the groundwaters of India, especially in the state of Andhra Pradesh, have so far yielded over 60 new crustacean taxa, belonging to Copepoda, Bathynellacea, Amphipoda, Isopoda, and Ostracoda (e.g., RANGA Reddy 2001, 2004, 2006, Karanovic \& Ranga Reddy 2004, Ranga Reddy \& Schminke 2005, Holsinger et al. 2006, Wilson \& Ranga Reddy 2011, Ranga Reddy \& Totakura 2010, 2012). The samples collected by one of the authors (YRR) from bore wells in Andhra Pradesh, under the auspices of a major research project contain representatives of a new stygobiotic amphipod species of Bogidiella Hertzog, 1933.

Bogidiellidae Hertzog, 1936 is composed of stygobiotic and interstitial amphipods, living in subterranean waters, including caves, wells, cold mountain springs at about 2,500 m altitude, and interstitial groundwater habitats (KoENEMANN \& Holsinger 1999). A single bogidiellid species from a cave on Borrow Island, Western Australia, Bogidomma australis Bradbury \& Williams, 1996, presents eyes, but is otherwise stygobiotic (IANNILLI et al. 2006). The bogidiellids do not present a Tethyan pattern of distribution, like some other subterranean Malacostraca, e.g., the amphipod hadziids, thermosbaenaceans, and cirolanid isopods (Sтоск 1976, 1977a, b, 1981). They are cosmopolitan, though concentrated in North America, South America, and Southern Europe. Some species also occur in Asia Minor, Eastern Africa, Arabian Peninsula, Asia, and Australia. Until now, Bogidiellidae contains 35 genera, with 105 described species (IANnilu et al. 2006).

This paper gives an illustrated description of a new species of Bogidiella. This is the second Indian species of Bogidiella, the first being Bogidiella indica Holsinger et al., 2006, which was also recorded in bore wells. The only two other stygobiotic amphipod species of India include Indoniphargus indicus (Chilton, 1923), which was reported from various groundwater habitats (e.g., springs, well water, mine pit) in the northeastern states of Bihar, West Bengal, and Odisha (formely Orissa), and Kotumsaria bastarensis Messouli et al., 2007, from Kotumsar Cave, Chhattisgarh state.

\section{MATERIAL AND METHODS}

The material examined was collected by plankton net, from bore wells in the state of Andhra Pradesh, Southern India. The collections were made on 24 April 2008, 26 June 2009, and 5 January 2010 . The specimens were found in the three collections, totaling 21 specimens. Specimens are housed at the Crustacea Collection of the Departamento de Zoologia, Instituto de Biologia, Universidade Federal do Rio de Janeiro (DZUFRJ), and at the National Collection of the Zoological Survey of India (ZSI), Kolkata, preserved in 70\% ethanol. Appendages and mouthparts were dissected and mounted on glass slides with gelatin-glycerol. Drawings were made under an optic microscopy (Motic BA-310) with camera lucida, and digitally prepared with CorelDraw X5, following a protocol based on Coleman (2003). All drawings were made based on the holotype DZUFRJ 4933. The setal/spine classification adopted in this paper follows WATLING (1989). Nomenclature of gnathopod palm is based on Poore \& Lowry (1997). 


\section{TAXONOMY}

\section{Bogidiella totakura sp. nov.}

Figs 1-22

Diagnosis. A stygomorphic bogidiellid amphipod with accessory flagellum 3-articulate, article 3 reduced, total length of accessory flagellum as long as articles 1 and 2 of flagellum combined; left mandible, molar broad, right mandible, molar absent; pereopod 5, slightly short, about 0.9 times the pereopod 6 and half as long as pereopod 7; telson about 1.3 times wider than long, notched at about $1 / 3$ of its length, apically truncate, with 1 apicolateral cusp in each lobe and 1 subapical stout seta on lateral margins.

Description. Description based on holotype, female, 1.0 mm (ZSI C 6024/2). Body slender. Head without eyes, longer than deep, about as long as pereonites 1 and 2 combined; lateral cephalic lobe produced, rounded. Antenna 1, about 0.4 times body length, peduncle slightly shorter than flagellum, article 1 slightly shorter than articles 2 and 3 combined, ratio of peduncular articles 1-3 = 1.9:1.2:1; flagellum 8-articulate, articles 1 to 6 each with 1 elongate aesthetasc; accessory flagellum 3-articulate, article 3 reduced, total length of accessory flagellum as long as articles 1 and 2 of flagellum combined. Antenna 2, about 0.7 times the length of antenna 2, peduncle twice as long as flagellum, article 5 slightly shorter than article 4; flagellum 5-articulate.

Maxilla 1, inner plate suboval, about half the length of outer plate; outer plate subrectangular, bearing 6 simple setae on apical margin; palp 2-articulate, article 2 tapering distally, with 1 apical and 1 subapical simple seta. Maxilla 2, short, both plates narrow, subequal in length, outer plate with 4 apical slender setae, inner plate with 4 apical slender setae plus 1 elongate seta near distolateral corner. Left mandible, molar broad, semitriturative; accessory setal row consisting of 2 small curved simple setae; lacinia mobilis present, well developed, broad and apically multi-cuspidate; incisor multi-cuspidate, one of the cusps more developed and acute than others; palp 3-articulate, article 1 short, about 1.8 times wider than long, with a dorsal long slender seta, article 2 slightly robust, about 2.2 times longer than wide, and about 1.8 times longer than article 3 , ventral margin convex, with a single slender seta, article 3 subrectangular, apically truncate, with 2 apical and 1 subapical slender setae. Right mandible subequal to left mandible, but molar absent, and article 1 of palp about as long as wide, without setae. Upper lip and lower lip in common with characteristics of the genus. Maxilliped, inner and outer plates short; inner plate suboval, with 1 apical and 1 subapical setae, and 3 distal setules; outer plate slightly elongate, with 1 seta and 2 setules distally; palp 4-articulate, stout, article 2 with 2 nodules, each with an apical long seta, about 1.6 times longer than article 3 , article 4 tapering distally, inner margin concave and setulose, claw present.

Gnathopod 1, coxa subrectangular, about twice as long as deep; basis robust, about 2.4 times longer than wide, poste- riorly produced and convex, with 1 distal slender seta, anterior margin almost straight, naked; ischium, posterior margin with a distal slender seta; merus subtriangular, twice as long as deep, posterior margin setose, posterodistal corner bearing a long stout seta; carpus, about 1.6 times deeper than long, with well developed posterior lobe bearing 2 long and 1 small apical setae, posterior margin with 2 parallel long setae between basis of posterior lobe and articulation with propodus; propodus suboval, about 2.4 times longer than carpus, and about 1.8 times longer than deep, palm acute, sinuous, about 1.5 times longer than posterior margin, bearing 2 marginal slender setae and 1 displaced slender seta near the palmar corner, the latter defined by small stout seta, posterior margin with a distal stout seta; dactylus curved, long, as long as palm, bearing a single slender seta at the outer margin. Gnathopod 2 , coxa small, subtriangular, about twice as long as deep; basis suboval, about 2.6 times longer than wide, anterior and posterior margins naked; merus subrectangular, about 1.2 times longer than wide, with 1 slender seta at the posterodistal corner; carpus subtriangular, about 1.3 times longer than wide, anterior margin naked, posterior margin convex, with 2 slender setae; propodus suboval, about 1.8 times longer than wide, anterior margin slightly convex, naked, anterodistal corner with 2 slender setae, palm extremely acute, bearing 4 stout setae, three of them attached to inner face of propodus, and another one to lateral face, palm about twice longer than posterior margin, palmar corner defined by a stout seta; dactylus curved, stout, about half as long as palm, without setae.

Pereopod 3 slender and weakly setose; basis slender, suboval, about twice longer than wide, anterior and posterior margins naked; merus about 2.5 times longer than wide; carpus subrectangular, about $75 \%$ of the merus length; propodus slender, about 4 times longer than wide; dactylus slightly curved, nail present. Pereopod 4 subequal to pereopod 3. Pereopod 5 , slightly short, about 0.9 times the pereopod 6 and half as long as pereopod 7; basis suboval, about 2.3 times longer than wide, anterior and posterior margins glabrous, anterodistal corner with 1 slender seta; merus 1.3 times longer than carpus, posterodistal corner with 1 curved stout seta; carpus with 2 anterodistal slender setae; propodus elongate, 5.6 times longer than wide, anterior and posterior margins naked, anterodistal corner with 1 small stout seta, curved backwards; dactylus stout, about 1.2 longer than wide, apically truncate, claw present. Pereopod 6, basis suboval, about 2.4 times longer than wide, anterior and posterior margins naked, anterodistal corner with 1 slender seta; merus about 1.5 times longer than carpus, posterodistal corner with a blunt stout seta; carpus, anterior margin with 1 stout seta, anterodistal and posterodistal corners with 1 curved stout seta each; propodus elongate, about 4.6 times longer than wide, anterodistal corner with 1 small stout seta, posterodistal corner with 1 stout seta; dactylus slender, claw present. Pereopod 7, slightly expanded posteriorly, about 1.8 times longer than wide, anterior and posterior mar- 


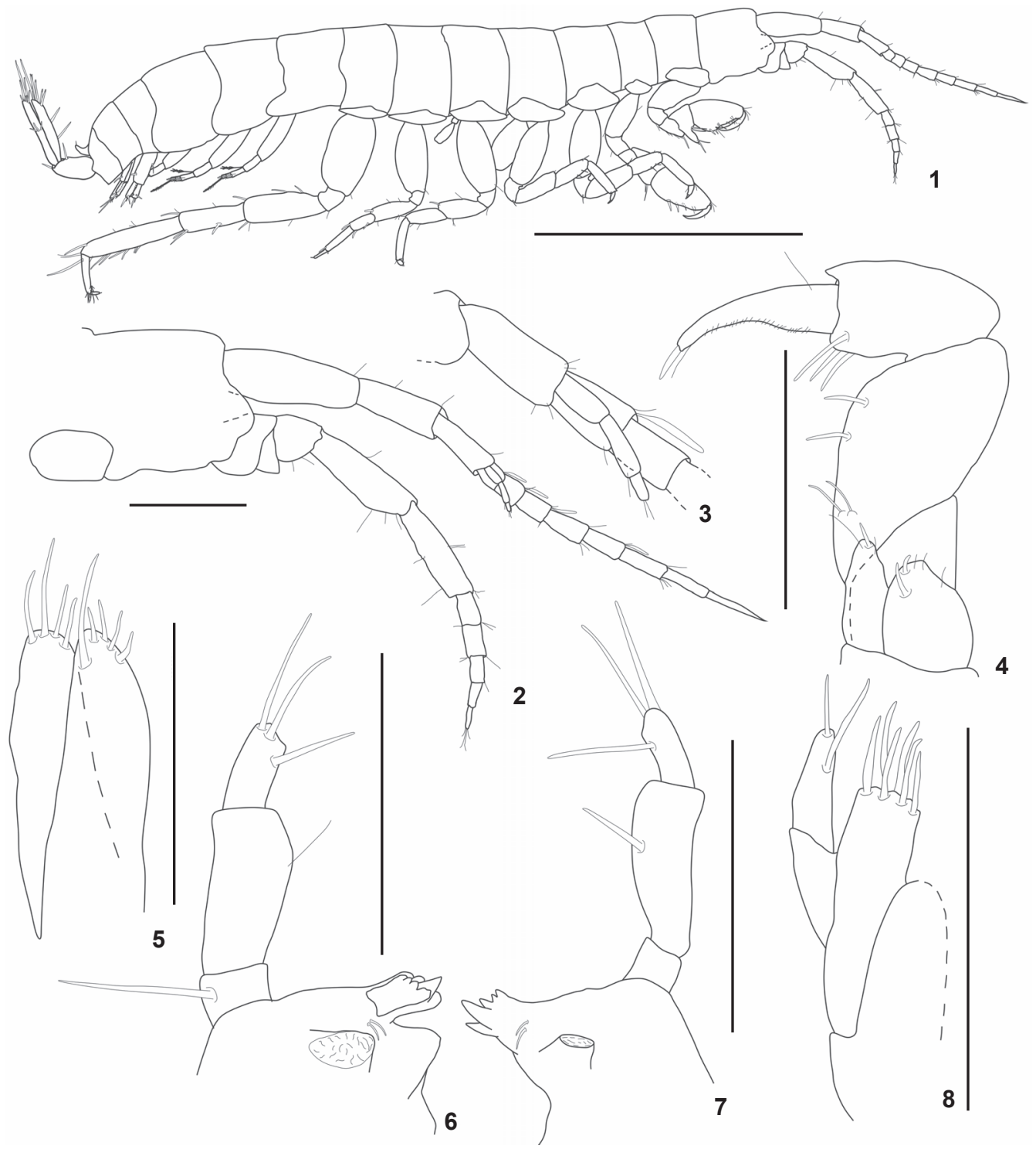

Figures 1-8. Bogidiella totakura sp. nov., holotype, female: (1) habitus; (2) head and antennae 1-2; (3) antenna 1, accessory flagellum; (4) maxilliped; (5) maxilla 2; (6) left mandible; (7) right mandible; (8) maxilla 1 . Scale bars: $1=0.5 \mathrm{~mm} ; 2=0.2 \mathrm{~mm} ; 3-8=0.1 \mathrm{~mm}$.

gins naked; merus about 2.9 times longer than wide and about 1.2 times longer than carpus, posterior margin with 2 stout setae, anterodistal and posterodistal corners with 1 seta each; carpus subrectangular, about 3.3 times longer than wide, 0.6 times the propodus length, bearing 1 stout seta on anterior margin, 2 setae at anterodistal corner and 1 seta at posterodistal corner; propodus elongate, about 5.7 times longer than wide, anterior margin setose, posterodistal corner with 2 long setae; dactylus slender, distally setose, posterior margin with 1 long proximal seta, claw present. Oostegites on present from pereonite 2 to 5 . Coxal gill observed only on pereonite 4 .
Pleopods 1-3 similar in shape and size, without inner ramus, outer ramus reduced in length. Epimeral plates 1 to 3 posteriorly produced and rounded, ventral and posterior margins naked. Uropod 1, peduncle subrectangular, about 2.9 times longer than wide, subequal in length to peduncle of uropod 2 , inner margin with 1 proximal stout seta, posterior margin with 1 distal stout seta; outer ramus slightly longer than inner ramus, about half length of peduncle, with 2 apical stout setae, 1 long and 1 short, and 1 subapical stout seta; inner ramus 1.25 times longer than outer ramus, about 0.8 times the peduncle length, apically truncate, bearing 3 apical setae, 1 elon- 


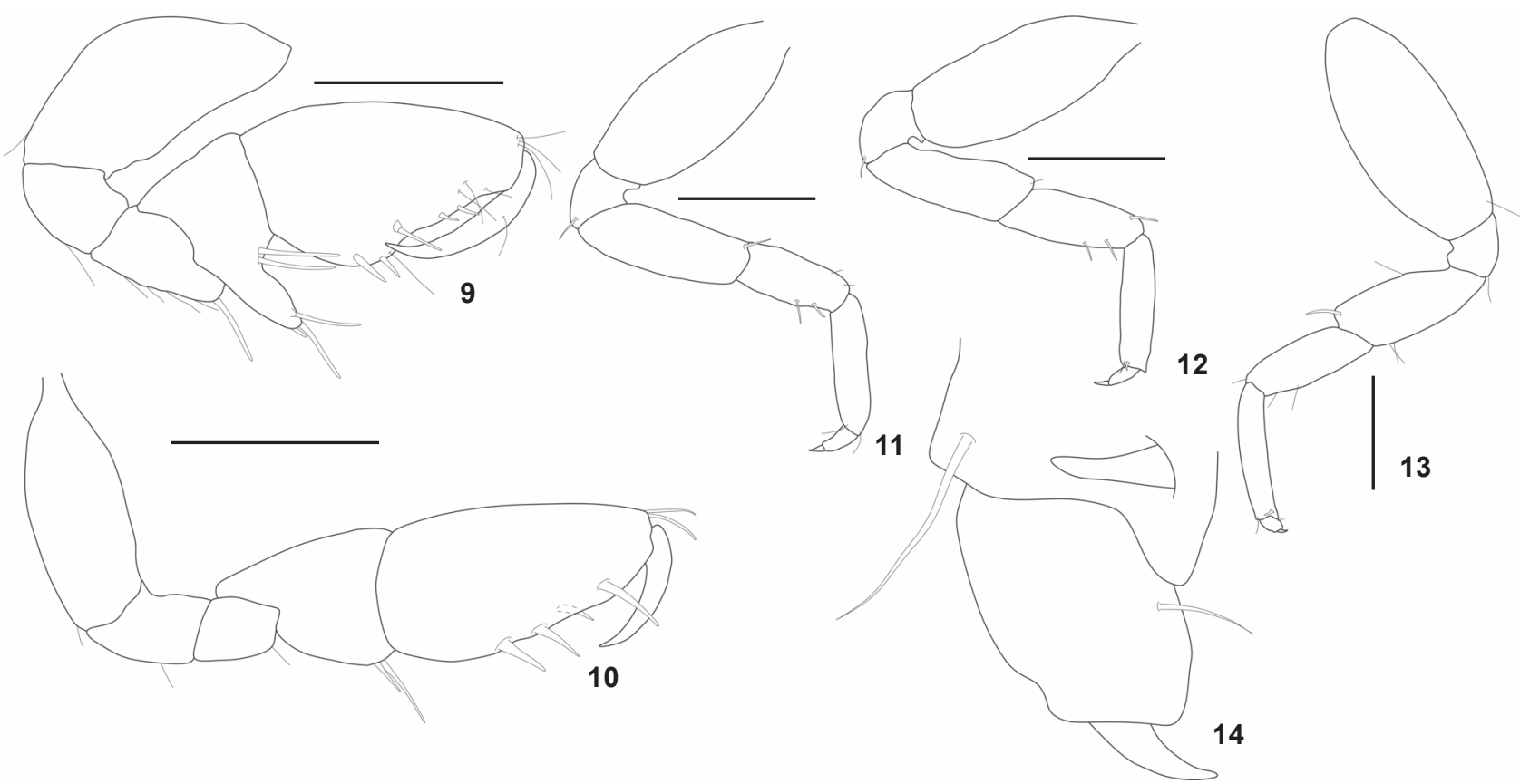

Figures 9-14. Bogidiella totakura sp. nov., holotype, female: (9) gnathopod 1; (10) gnathopod 2; (11) pereopod 3; (12) pereopod 4; (13) pereopod 5; (14) pereopod 5 detail, propodus and dactylus. Scale bars: $0.1 \mathrm{~mm}$.

gate and 2 short; outer ramus apically obtuse, bearing 3 apical setae, 1 elongate and 2 short. Uropod 2, peduncle about 2.5 times longer than wide, dorsal margin with 1 distal seta; inner ramus about 1.3 times longer than outer ramus, subrectangular; outer ramus bearing 1 elongate and 2 small setae apically. Uropod 3, peduncle about twice longer than wide, dorsal margin with 1 distal stout seta, ventral margin with 1 distal stout seta; rami elongate, subequal in length, about 1.8 times longer than peduncle; outer ramus with a set of 3 small stout setae at its mid-length, apical margin with 7 setae of variable length; inner ramus, dorsal margin with 2 long stout setae, apical margin with 6 setae of variable length. Telson flattened and mobile, about 1.3 times wider than long, notched at about $1 / 3$ of its length, apically truncate, with 1 apicolateral cusp in each lobe and 1 subapical stout seta on either lateral margin.

Material examined. Holotype female, $1.0 \mathrm{~mm}$, InDIA, Andhra Pradesh State: Guntur District (in the vicinity of Kundranapalli Village, near Vijayawada, $16^{\circ} 28^{\prime} 02.1 " \mathrm{~N}$, $80^{\circ} 36^{\prime} 28.2^{\prime \prime E}$, elevation $22 \mathrm{~m}$, Bore well), 5 January 2010, Y. Ranga Reddy leg., ZSI C 6024/2. Patatypes: 5 specimens, InDIA, Andhra Pradesh State: Guntur District (in the vicinity of Kunchanapalli Village, near Vijayawada, $16^{\circ} 28^{\prime} 02.1^{\prime \prime} \mathrm{N}, 80^{\circ} 36^{\prime} 28.2^{\prime \prime} \mathrm{E}$, elevation 22 m, bore well), 5 January 2010, Y. Ranga Reddy leg., DZUFRJ 4933; 1 specimen, Prakasan District (Anikapalli Village, near CS Puram, $15^{\circ} 10.163^{\prime} \mathrm{N}, 79^{\circ} 17.321^{\prime} \mathrm{E}$, elevation $146 \mathrm{~m}$, bore well), 24 April 2008, Y. Ranga Reddy leg., DZUFRJ 4934; 6 specimens, (Divili Village, E. Godavari, near Samalkot, bore well), 26 June
2009, Y. Ranga Reddy leg., DZUFRJ 4935; 2 specimens, Prakasan District (Anikapalli Village, near CS Puram, $15^{\circ} 10.163^{\prime} \mathrm{N}$, $79^{\circ} 17.321^{\prime} \mathrm{E}$, elevation $146 \mathrm{~m}$, bore well), 24 April 2008, Y. Ranga Reddy leg., ZSI C 6025/2; 6 specimens, Guntur District (in the vicinity of Kunchanapalli Village, near Vijayawada, $16^{\circ} 28^{\prime} 02.1^{\prime \prime} \mathrm{N}$, $80^{\circ} 36^{\prime} 28.2^{\prime \prime}$, elevation $22 \mathrm{~m}$, bore well), 5 January 2010, Y. Ranga Reddy leg., ZSI C 6026/2.

Etymology. The name of species is dedicated to Mr. V.R. Totakura, a promising young researcher and a student of Y.R.R., who was the first to collect the sample of the new species.

\section{DISCUSSION}

Koenemann \& Holsinger (1999) discussed the phylogeny of Bogidiellidae and recognized a group of species closely related to B. niphargoides Ruffo \& Vigna Taglianti, 1977, with inner rami of pleopods either reduced or absent. This group includes B. cooki Grosso \& Ringuelet, 1979, B. thai Botosaneanu \& Notenboom, 1988, and B. vomeroi Ruffo \& Vigna Taglianti, 1977. Subsequently, Holsinger et al. (2006) described B. indica, also with pleopodal inner rami absent, similarly to $B$. totakura sp. nov. Hence both species will be discussed as part of the $B$. niphargoides group.

Bogidiella totakura sp. nov. shares the diagnostic characters of the genus: body elongate and vermiform; eyes absent; coxae wider than long; carpus of gnathopod 1 with posterodistal projection; propodus of gnathopod 2 shorter than that of 


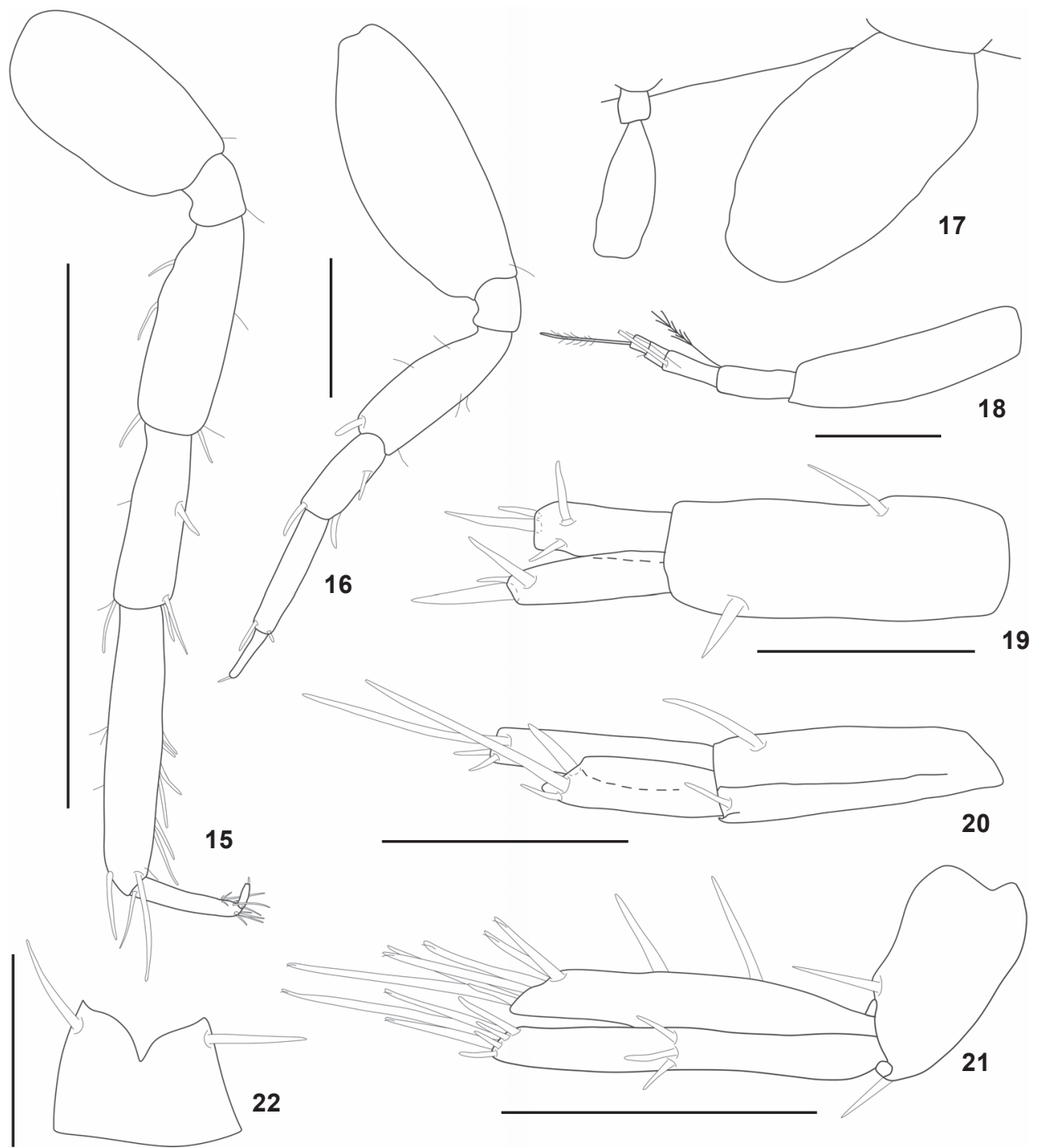

Figures 15-22. Bogidiella totakura sp. nov., holotype, female: (15) pereopod 7; (16) pereopod 6; (17) oostegite, on pereonite 3, and coxal gill, on pereonite 4 ; (18) pleopod 1; (19) uropod 1; (20) uropod 2; (21) uropod 3; (22) telson. Scale bars: $15=0.5 \mathrm{~mm} ; 22=0.2 \mathrm{~mm} ; 16$ 20 and $22=0.1 \mathrm{~mm}$.

gnathopod 1; external gills inserted from coxae 4 to 6; pleopods with inner ramus undivided, reduced or absent, outer ramus 3articulate; uropod 3 birramous, with elongate rami, outer ramus 1-articulate; telson entire (diagnostic characters of the family); maxilla 1 with inner plate setose and palp 2-articulate; maxilla 2 with plates densely setose; mandible with palp robust, 3-articulate; maxilliped with plates well developed, with slender and stout setae; coxae 5 and 6 without posteroventral lobe; uropod 2 with rami unmodified to transfer sperm; and sexual dimorphism absent.

The new species is similar to $B$. indica by pleopods $1-3$ having no inner ramus. However, it can be easily separated from the latter by (character states of $B$. indica in parentheses): body small, 1.0-1.5 $\mathrm{mm}$ (3.5-5.5 $\mathrm{mm})$; lateral cephalic lobe rounded (subacute, rounded only in the apex); accessory flagellum 3-articulate (1-articulate), subequal in length to articles 1 and 2 of flagellum combined (not exceeding the length of first flagellar segment); pereopod 5 proportional in length to pereopods 6 and 7 (strongly disproportionate); uropod 1, peduncle about 1.3 times the length of peduncle of uropod 2 (about twice the length), apical setae of rami simple (dorsally serrate); telson, apical margin notched (smooth).

Bogidiella totakura sp. nov. is distinguished from B. cooki by the following characters: (character states of $B$. cook in pa- 
rentheses): antenna 1 , flagellum 8 -articulate (17-articulate); accessory flagellum 3 -articulate (2-articulate, article 2 being minute); maxilla 1 , outer plate with simple setae (multi-cuspidate setae); mandible, palp article 2 stout (slender), article 3 with 2 apical and 1 subapical seta (1 apical seta); gnathopod 2, propodus suboval (subrectangular), palm extremely acute, longer than posterior margin, bearing 3 stout setae (slightly acute, shorter than palm, densely setose); pereopods 5-7, basis with posterior margin lacking concavities (with a distal concavity); pleopods, inner ramus absent (reduced); telson notched at about $1 / 3$ of its length (entire).

Compared to Bogidiella vomeroi Ruffo \& Vigna Taglianti, 1977, the new species can be recognized by (characters of $B$. vomeroi in parentheses): gnathopod 2 , palm extremely acute and palmar corner defined by a stout seta (palm slightly acute and palmar corner defined by the angle between palm and posterior margin); uropod 3, rami about 1.8 times longer than peduncle (2.2 times longer than peduncle); telson notched at about $1 / 3$ of its length, apically truncate, with 1 apicolateral cusp on each lobe (distal margin deeply concave, lobes apically rounded).

From Bogidiella niphargoides Ruffo \& Vigna Taglianti, 1977, the new species can be distinguished by the following characters (characters of $B$. niphargoides in parentheses): antenna 1 , accessory flagellum 3 -articulate (2-articulate); mandible, article 3 of palp robust, about 2.2 times longer than wide (elongate, about 4.8 times longer than wide); shape and ornamentation of propodus of gnathopods 1-2, suboval, with some stout setae irregularly distributed on the palm (elongate, with anterior margin almost straight, palm continuously setose); uropod 3, rami about 1.8 times longer than peduncle ( 2.2 times longer than peduncle); telson notched at about $1 / 3$ of its length (telson entire).

Finally, Bogidiella totakura sp. nov. can be distinguished from Bogidiella thai Botosaneanu \& Notenboom, 1988 by (characters of $B$. thai in parentheses): antenna 1, accessory flagellum 3 -articulate (2-articulate, being article 1 extremely elongate); anterior coxae separate (slightly overlapping); maxilla 1, outer plate bearing 6 simple setae in the apical margin, palp with 1 apical and 1 subapical simple seta (outer plate bearing 7 multi-cuspidate setae in the apical margin, palp with 5 plumose apical seta); gnathopods 1-2, propodus suboval (propodus subrectangular), gnathopod 2, palm extremely acute, dactylus reaching the half length of palm (palm moderately acute, dactylus as long as palm); telson notched at about $1 / 3$ of its length (telson entire). This study updates the number of known species of Bogidiellidae to 106.

\section{ACKNOWLEDGEMENTS}

This study was financially supported by Fundação Carlos Chagas Filho de Amparo à Pesquisa do Estado do Rio de Janeiro (FAPERJ), Coordenação de Aperfeiçoamento de Pessoal de Nível Superior (CAPES), and also by the Department of Science \&
Technology, Ministry of Science \& Technology, New Delhi, India. The authors are also grateful to Adriano B. Kury, from Museu Nacional, Universidade Federal do Rio de Janeiro (MN/ UFRJ), for his valuable comments on this manuscript.

\section{LITERATURE CITED}

Coleman, C.O. 2003. "Digital inking": How to make perfect line drawings on computers? Organisms, Diversity and Evolution 3 (14): 1-14.

Holsinger, J.R.; Y. Ranga Reddy \& M. Messouli. 2006. Bogidiella indica, a new species of subterranean Amphipod Crustacean (Bogidiellidae) from wells in Southeastern India, with remarks on the biogeographic importance of recently discovered Bogidiellids on the Indian subcontinent. Subterranean Biology 4: 45-54.

Iannilli, V.; J.R. Holsinger; S. Ruffo \& R. Vonk. 2006. Two new genera and two new species of the subterranean family Bogidiellidae (Crustacea, Amphipoda) from groundwaters in northern Oman, with notes on the geographic distribution of the family. Zootaxa 1208: 37-56.

Karanovic, T. \& Y. Ranga Reddy. 2004. A new genus and species of the family Diosaccidae (Copepoda: Harpacticoida) from the ground waters of India. Journal of Crustacean Biology 24: 246-260.

Koenemann, S. \& J.R. Holsinger. 1999. Phylogenetic analysis of the Amphipod family Bogidiellidaes. lat., and revision of taxa above the species level. Crustaceana 72 (8): 781-816.

Poore, A.G.B. \& J.K. Lowry. 1997. New ampithoid amphipods from Port Jackson, New South Wales, Australia (Crustacea: Amphipoda: Ampithoidae). Invertebrate Taxonomy 11: 897-941.

Ranga RedDy, Y. 2001. Discovery of Parastenocarididae (Copepoda, Harpacticoida) in India, with the description of three new species of Parastenocaris Kessler, 1913, from the River Krishna at Vijayawada. Crustaceana 74 (8): 705-733.

Ranga Reddy, Y. 2004. Existence of the Order Bathynellacea (Crustacea, Syncarida) in South Asia: a new species of the genus Habrobathynella Schminke from River Pennar, South India. Journal of the Bombay Natural History Society 101 (2): $277-284$.

Ranga Reddy, Y. 2006. First Asian report of the genus Chilibathynella Noodt, 1963 (Bathynellacea, Syncarida), with the description and biogeographic significance of a new species from Kotumsar Cave, India. Zootaxa 1370: 23-37.

Ranga Reddy, Y. \& H.K. Schminke. 2005. A new bathynellid from India with unusual mouthparts (Bathynellacea: Bathynellidae). Journal of Crustacean Biology 25 (1): 25-30.

Ranga Reddy, Y. \& V.R. TotakuRa. 2010. A taxonomic revision of the genus Habrobathynella Schminke, 1973, with the description of four new species from southeastern India (Crustacea, Malacostraca, Bathynellacea). Zootaxa 2532: 1-54.

RANGa Reddy, Y. \& V.R. TotakURA. 2012. Indobathynella prehensilis gen. et sp. nov., an aberrant species of Bathynellacea (Eumala- 
costraca) from India. Journal of Crustacean Biology 32 (2): 281-293.

STock, J.H. 1976. A new genus and two new species of the crustacean order Thermosbaenacea from the West Indies. Bijdragen tot de Dierkunde 46 (1): 47-70.

Sтоск, J.H. 1977a. Microparasellidae (Isopoda, Asellota) from Bonaire - with notes on the origin of the family. Studies on the fauna of Curaçao and other Caribbean islands 51 (168): 69-91.

Sтоск, J.H. 1977b. The taxonomy and zoogeography of the hadziid Amphipoda, with emphasis on the West Indian taxa. Studies on the fauna of Curaçao and other Caribbean islands 55 (177): 1-130.
Sтоск, J.H. 1981. The taxonomy and zoogeography of the family Bogidiellidae (Crustacea, Amphipoda), with emphasis on the West Indian taxa. Bijdragen tot de Dierkunde 51 (2): 345-374.

WatuInG, L. 1989. A classification of crustacean setae based on the homology concept, p. 15-26. In: B.E. Felgenhauer; A.B. Thistle \& L. Watling (Eds). Functional Morphology of Feeding and Grooming in Crustacea. New York, CRC Press, Crustacean Issues, vol. 6.

Wilson, G.D.F. \& Y. RANGA RedDy. 2011. Andhracoides shabuddin gen. nov., sp. nov., a new phreatoicidean isopod (Crustacea, Hypsimetopidae) from hypogean aquatic habitats in Andhra Pradesh, India. Zootaxa 2869: 35-53.

Submitted: 09.III.2013; Accepted: 15.VI.2013.

Editorial responsibility: Marcos D.S. Tavares 